OPEN ACCESS

Edited by:

Sabita Roy,

University of Miami, United States

Reviewed by:

Sergio Iván Valdés-Ferrer, Instituto Nacional de Ciencias Médicas y Nutrición Salvador Zubirán

(INCMNSZ), Mexico

Nazira El-Hage,

Florida International University, United States

${ }^{*}$ Correspondence:

Wen-Zhe Ho

wenzheho@temple.edu

Specialty section:

This article was submitted to Inflammation,

a section of the journal

Frontiers in Immunology

Received: 10 July 2019 Accepted: 21 October 2019 Published: 15 November 2019

Citation:

Wang X, Liu J, Zhou L and Ho W-Z

(2019) Morphine Withdrawal

Enhances HIV Infection of Macrophages.

Front. Immunol. 10:2601. doi: 10.3389/fimmu.2019.02601

\section{Morphine Withdrawal Enhances HIV Infection of Macrophages}

\author{
Xu Wang, Jinbiao Liu, Lina Zhou and Wen-Zhe Ho* \\ Department of Pathology and Laboratory Medicine, Lewis Katz School of Medicine, Temple University, Philadelphia, PA, \\ United States
}

Opioid withdrawal recurs at high rates in opioid use disorder and compromises the immune system. In general, there are two types of opioid withdrawal: abrupt withdrawal (AW) and precipitated withdrawal (PW). In this study, we examined the effect of morphine AW or morphine PW on HIV infection of human blood monocyte-derived macrophages. We observed that both morphine AW and PW enhanced the susceptibility of macrophages to HIV infection. In addition, both AW and PW activated HIV replication in the latently infected myeloid cells (U1 and OM10.1). Investigation of mechanisms responsible for these observations showed that both AW and PW could inhibit the expression of multiple intracellular HIV inhibitory factors, including APOBE3G/F, SAMHD1, MX2, and HIV restriction microRNAs (miR-28, miR-125b, and miR-150) in macrophages. These findings provide additional evidence to support the notion that opioid use compromises the intracellular anti-HIV immunity and facilitates HIV infection and persistence in macrophages.

Keywords: morphine, abrupt withdrawal, precipitated withdrawal, microRNAs, HIV, macrophages

\section{INTRODUCTION}

Opioid withdrawal recurs at high rates in opioid use disorder and compromises the immune system $(1,2)$. Opioid tolerance has been studied extensively; once tolerance develops, discontinuing the drug with or without administering an opioid antagonist can progress to a state of physical dependence (2). While there are very few studies that examine the impact of morphine withdrawal on host immunity and HIV infection, it is known that opiate addiction compromises the immune system and facilitates HIV infection and replication. Early clinical and epidemiologic studies show that opioid use is a cofactor in the pathogenesis of HIV disease. Opioids modulate cytokine production/cell trafficking and, thereby, increase the vulnerability of the host cells to HIV infection $(3,4)$. Our earlier studies documented that morphine or methadone enhances HIV infection of macrophages and microglia (5-7). We also showed that heroin use facilities HIV infection of macrophages through inhibiting the expression of the HIV restriction miRNAs (8). These findings are clinically relevant and significant as macrophages have an important role in HIV infection during all stages of the disease where they act as key target cells and reservoirs, a means to other tissues in the body, and viral transmitters to $\mathrm{CD} 4^{+} \mathrm{T}$ cells.

The enhancing effect of opiates on HIV infection/replication is likely due to their negative impact on host immunity (9-11). The impact of opiates on the immune system has been extensively studied in T cells, B cells, macrophages, natural killer cells, and polymorphonuclear leukocytes (12-15). Although studies have demonstrated that opioids modulate the functions of macrophages, there is limited information about specific mechanism(s) of opioid effect on the intracellular immunity against HIV in macrophages. Previous studies concluded that morphine inhibited the production of 
type I interferons (IFNs) (16), the primary cytokines that regulate all immune stages and lead host innate immunity against viral infections. Upon exposure to viral infection, IFN$\alpha / \beta$ can activate downstream cell signaling, inducing multiple IFN-stimulated genes and other antiviral factors, including those HIV restriction miRNAs. Thus, it is of significance to examine whether opioid withdrawal inhibits intracellular antiHIV immunity in macrophages and facilitates HIV infection and replication.

\section{MATERIALS AND METHODS}

\section{Primary Cells and Cell Lines}

Purified primary human monocytes from peripheral blood were obtained from the Human Immunology Core at the University of Pennsylvania (Philadelphia, PA, USA). The Human Immunology Core has the Institutional Review Board approval for blood collection from healthy donors. Freshly isolated monocytes were plated in 48-well culture plates (Corning CELLBIND Surface) at a density of $2.5 \times 10^{5}$ cells/well in DMEM containing $10 \%$ fetal calf serum (FCS), $1 \%$ non-essential amino acid, $1 \%$ L-glutamine, and $1 \%$ penicillin-streptomycin solution at $37^{\circ} \mathrm{C}$ with $5 \% \mathrm{CO}_{2}$. Monocyte-derived macrophages refer to 7-day-cultured monocytes in vitro. HIV-infected U1 and OM10.1 cell lines were provided by the AIDS Reagent Program, National Institutes of Health. U1 is a cloned cell line derived by limiting dilution cloning of U937 cells surviving an acute infection with HIV (LAV-1 strain); each cell has two copies of integrated HIV proviral DNA $(17,18)$. OM10.1 cells were cloned from HL-60 promyelocyte cells that endured an acute HIV infection. Each cell contains a single integrated provirus $(19,20)$. U1 and OM10.1 cells were cultured in RPMI1640 supplemented with 10\% FCS, 1\% L-glutamine, and $1 \%$ penicillin-streptomycin.

\section{Reagents and HIV Strain}

Morphine sulfate was provided by the National Institute of Drug Abuse (Rockville, MD). Naloxone was obtained from Sigma (St. Louis, MO). The macrophage-tropic R5 strain (Bal), an isolate from human infant lung tissue, was obtained from the AIDS Reagent Program, the National Institutes of Health, Bethesda, MD.

\section{Morphine Treatment and Withdrawal}

Seven-day-cultured macrophages $\left(2.5 \times 10^{5}\right.$ cells/well in 48 -well plates) were treated with or without morphine $\left(10^{-10} \mathrm{M}\right)$ for $96 \mathrm{~h}$ and morphine was then removed. For morphine abrupt withdrawal (AW), we removed morphine from the cell cultures by rigorously washing the cells three times with plain DMEM. For precipitated withdrawal (PW), morphine was removed from the cultures and then cells were treated with naloxone $\left(10^{-8}\right.$ M) (Figure 1). Cells were then subjected to RNA extraction and real-time RT-PCR at the time points indicated in the figure legends. U1 and OM10.1 cells in T-25 flasks were incubated with or without morphine $\left(10^{-8} \mathrm{M}\right)$ for $96 \mathrm{~h}$ and then plated in triplicate at a density of $10^{5}$ cells/well in 48 -well culture plates. Afterward, they were subjected to either AW or PW. The cells were stimulated with TNF- $\alpha(2 \mathrm{ng} / \mathrm{ml}) 2 \mathrm{~h}$ post morphine withdrawal. HIV RT activity in the culture supernatant was measured at $48 \mathrm{~h}$ post morphine withdrawal.

\section{HIV Infection}

Seven-day-cultured macrophages $\left(2.5 \times 10^{5}\right.$ cells/well in 48 -well plates) were treated with or without morphine $\left(10^{-10} \mathrm{M}\right)$ for $96 \mathrm{~h}$ and then morphine was removed from the cell cultures for $24 \mathrm{~h}$. The cells were infected with equal HIV Bal strain (p24 protein, 20 $\mathrm{ng} / 10^{6}$ cells) for $2 \mathrm{~h}$ at $37^{\circ} \mathrm{C}$. After infection, the cells were then washed three times with plain DMEM to remove the unabsorbed viruses. The final wash was tested for viral RT activity and found to be free of residual inoculum, as compared with untreated cells. Culture supernatant was collected at day 9 post-infection for HIV RT activity assay.

\section{HIV Reverse Transcriptase (RT) Assay}

Determination of HIV RT activity was adapted from Willey et al. (21). In brief, collected culture supernatant $(10 \mu \mathrm{l})$ was added to a cocktail containing poly (A) (GE Healthcare, Mickleton, $\mathrm{NJ}$ ), oligo (dT) (USB, Cleveland, $\mathrm{OH}$ ), $\mathrm{MgCl}_{2}$, and ${ }^{32} \mathrm{P}$ dTTP (PerkinElmer, Boston, MA) and incubated for $20 \mathrm{~h}$ at $37^{\circ} \mathrm{C}$. The cocktail $(30 \mu \mathrm{l})$ was spotted onto DE81 paper, dried, and washed five times with $2 \times$ saline-sodium citrate buffer and once with $95 \%$ ethanol. The filter paper was then air-dried. Radioactivity was counted in a liquid scintillation counter (PerkinElmer, Boston, PA).

\section{RNA Extraction and Reverse Transcription}

Total cellular RNA was isolated from macrophages using Trireagent (Molecular Research Center, Cincinnati, $\mathrm{OH}$ ). In brief, the total cellular RNA was extracted by a single step, guanidium thiocyanate-phenol-chloroform extraction. After centrifugation at $13,000 \mathrm{~g}$ for $15 \mathrm{~min}$ at $4^{\circ} \mathrm{C}$, the RNA-containing aqueous phase was collected and precipitated in isopropanol. The RNA precipitates were then washed once in $75 \%$ ethanol and re-suspended in $30 \mu \mathrm{l}$ of RNase-free water. Total RNA (1 $\mu \mathrm{g}$ ) was subjected to reverse transcription using the reverse transcription system (Promega, Madison, WI) according to the manufacturer's protocol. The cDNA was ready to serve as a template for PCR amplification. For miRNA reverse transcription, the total RNAs, including microRNAs, were reversely transcribed with miScript Reverse Transcription Kit (QIAGEN, Germantown, MD, USA).

\section{qRT-PCR for mRNA and microRNA}

Real-time PCR was performed with the iQ SYBRGreen Supermix (Bio-Rad Laboratories, Hercules, CA, USA) as previously described. The oligonucleotide primers were synthesized by Integrated DNA Technologies, Inc. (Coralville, IA, USA), and sequences will be available upon request. Real-time PCR for the quantification of microRNAs (miRNA-28, miRNA-125b, miRNA-150, miRNA-132, miRNA-124a, Let-7C, and RNU5A) was conducted with miScript Primer Assays and miScript SYBR Green PCR Kit (QIAGEN, Germantown, MD, USA) as instructed by the manufacturer. 


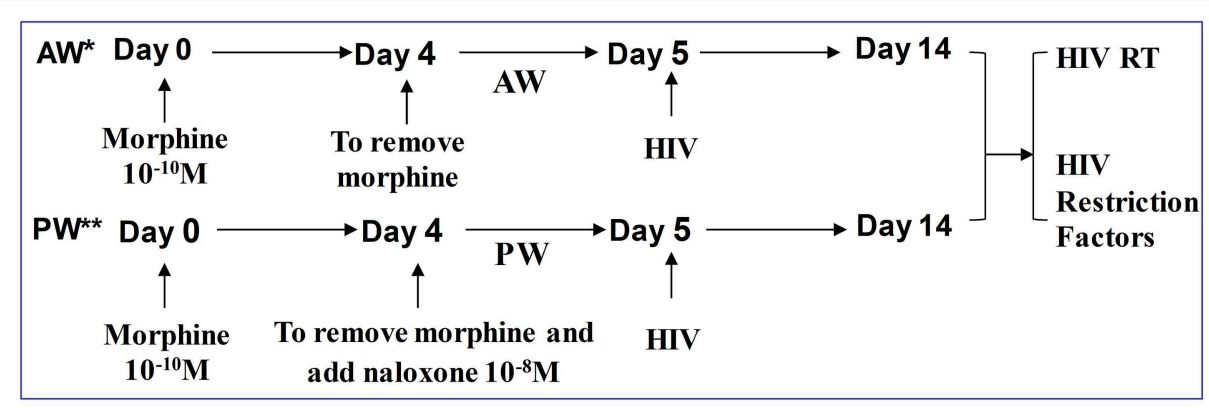

* AW: Abrupt withdrawal;

** PW: Precipitated withdrawal.

FIGURE 1 | Experimental design to determine the effect of morphine withdrawal on HIV infection of primary human macrophages. Seven-day-cultured macrophages were incubated with or without morphine $\left(10^{-10} \mathrm{M}\right)$ for $96 \mathrm{~h}$ and then subjected to morphine AW or PW for $24 \mathrm{~h}$. For AW, we removed morphine from the cell cultures by washing the cells three times with plain DMEM. For PW, the cells were treated with naloxone $\left(10^{-8} \mathrm{M}\right) 3 \mathrm{~min}$ after morphine AW. The cells undergoing morphine AW or PW as described above were infected with equal amounts (HIV p24, $20 \mathrm{ng} / 10^{6}$ cells) of cell-free HIV Bal strain for $2 \mathrm{~h}$. The cells were then washed three times with plain DMEM to remove unabsorbed HIV $24 \mathrm{~h}$ after infection. Supernatants were collected from HIV-infected cell cultures for HIV RT activity assay at day 9 post-infection (day 14 after morphine treatment).

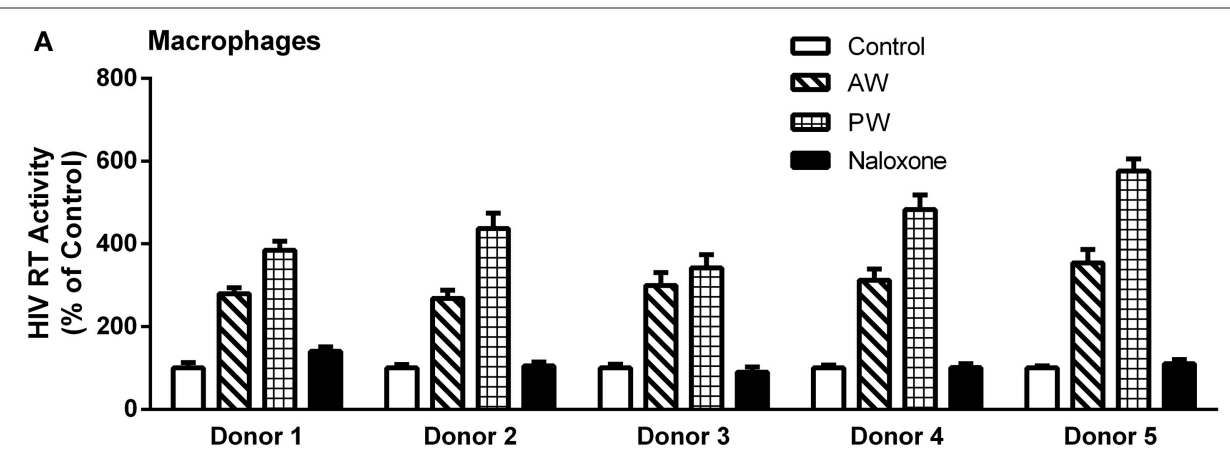

B

$$
\text { U1 Cell }
$$

C
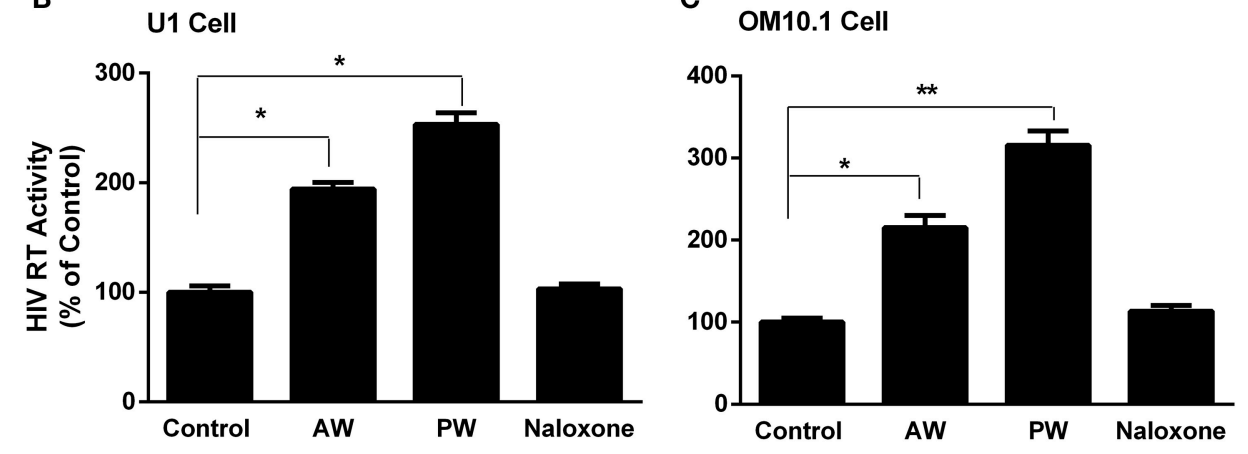

FIGURE 2 | Effect of AW or PW on HIV replication in macrophages, U1, and OM10.1 cells. (A) Seven-day-cultured macrophages were incubated with or without morphine $\left(10^{-10} \mathrm{M}\right)$ for $96 \mathrm{~h}$, followed by morphine AW or PW for $24 \mathrm{~h}$. For PW, naloxone $\left(10^{-8} \mathrm{M}\right)$ was added to the cell cultures 3 min after morphine was removed. The cells were then infected with HIV (Bal) for $2 \mathrm{~h}$. HIV RT activity was measured in culture supernatant collected at day 9 after infection. The data shown are the mean $\pm \mathrm{SD}$ of triplicate determinations, five independent experiments using macrophages from five different donors. (B,C) U1 cells and OM10.1 cells were incubated with or without morphine $\left(10^{-8} \mathrm{M}\right)$ for $96 \mathrm{~h}$ and then subjected to morphine AW or PW. The cells were stimulated with TNF- $\alpha(2 \mathrm{ng} / \mathrm{ml}) 2 \mathrm{~h}$ post-withdrawal. HIV RT activity was measured in culture supernatant $48 \mathrm{~h}$ post-withdrawal. The data shown are the mean $\pm \mathrm{SD}$ of triplicate determinations, representative of three independent experiments $\left({ }^{*} p<0.05,{ }^{\star *} p<0.01\right.$, AW or PW vs. control).

\section{Statistical Analysis}

Where applicable, data were expressed as mean $\pm \mathrm{SD}$. To compare the mean of the two groups (AW or PW treated vs. untreated control cells), statistical significance was measured by ANOVA with the appropriate post-hoc test. Statistical analyses were conducted with SPSS 18.0 software (SPSS Inc., Chicago, IL, USA). Statistical significance was defined as $p<0.05$. 


\section{RESULTS}

\section{Effect of Morphine AW or PW on Acute and Latent HIV Infection}

We first examined whether AW or PW enhances acute HIV infection of primary human macrophages. As demonstrated in Figure 2A, either AW or PW could enhance the HIV infection of macrophages. We also examined the effect of morphine AW or PW on TNF- $\alpha$-induced HIV replication in latently infected cell lines. As shown in Figures 2B,C, both morphine AW and PW could activate and enhance TNF- $\alpha$-induced HIV replication in $\mathrm{U} 1$ and OM10.1 cells.

\section{Effect of Morphine AW or PW on miRNAs Related to HIV Infection in Macrophages}

Our early study (22) demonstrated that freshly isolated monocytes from human blood expressed significantly higher levels of the cellular anti-HIV miRNAs (miRNA28, miRNA-150, miRNA-223, and miRNA-382) than donor matched macrophages. These miRNAs play a key role in suppressing HIV replication in monocytes and macrophages $(11,22)$. Thus, we examined whether morphine AW or PW inhibits the expression of these HIV restriction mRNAs in macrophages. As shown in Figure 3, both morphine AW and PW significantly decreased the expression of the
HIV restriction miRNA (miR-28, miR-125b, and miR150) (Figure 3A) and increased HIV enhancing miRNA $(23,24)$ (miR132, miR124a, and let-7C) in macrophages (Figure 3B).

\section{Effect of Morphine AW or PW on HIV Restriction Factor in Macrophages}

We next examined the effect of morphine AW or PW on the expression of the intracellular HIV restriction factors. As shown in Figure 4, both morphine AW and PW significantly inhibited the expression of apolipoprotein B mRNA-editing enzyme, catalytic polypeptide-like 3G/F (APOBEC3G/F), SAM domain and HD domain-containing protein 1 (SAMHD1), and MX dynamin-like GTPase 2 (MX2) at $6 \mathrm{~h}$ post morphine withdrawal.

\section{DISCUSSION}

In this study, we demonstrated that both morphine AW and PW significantly enhanced acute HIV infection of primary human macrophages (Figure 2A). In addition, we found that either morphine AW or PW could activate HIV replication in latently infected myeloid cells (U1 and OM10.1, Figures 2B,C). These observations support an early in vivo study using the non-human primate model, showing that precipitated morphine

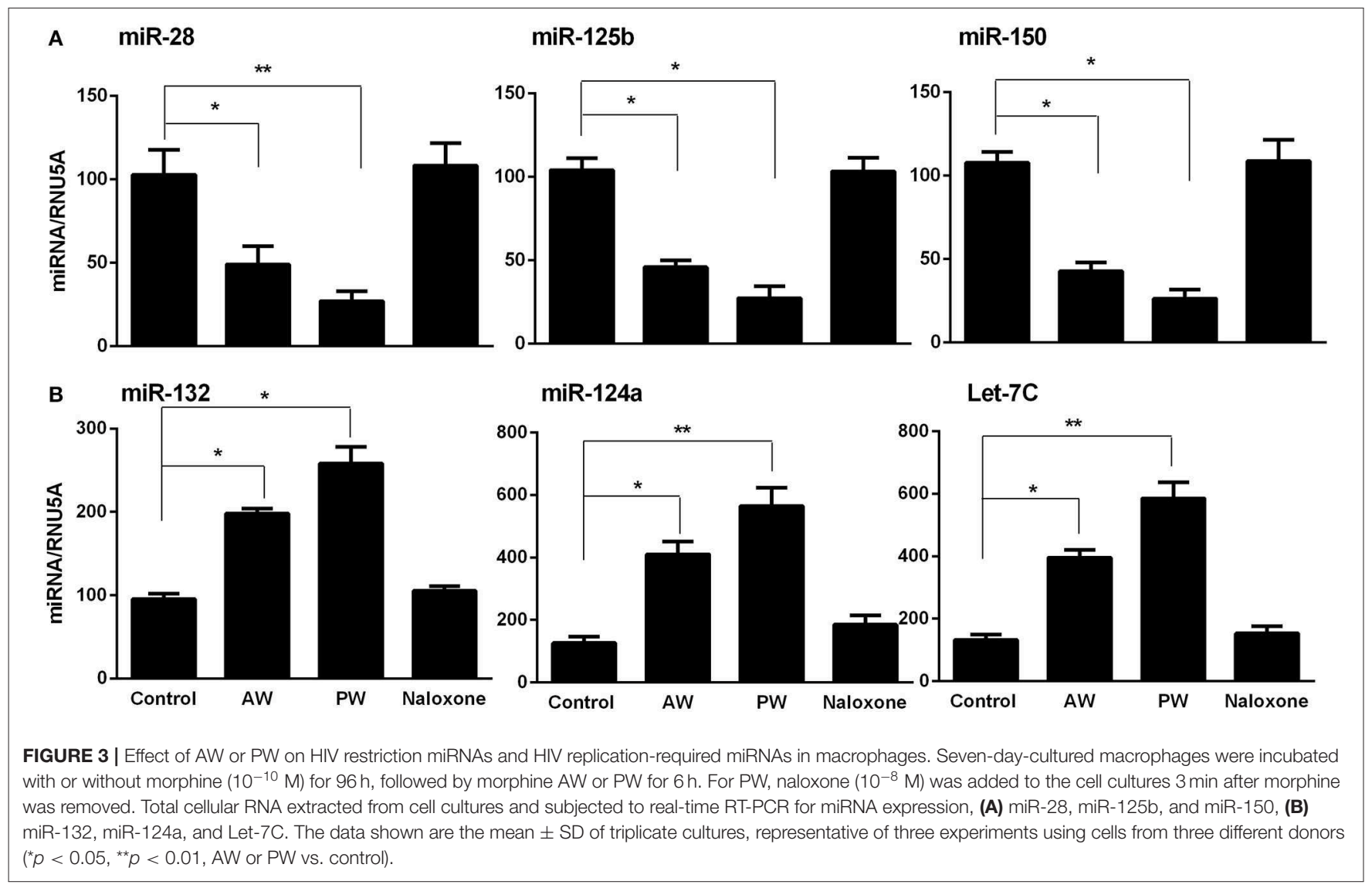



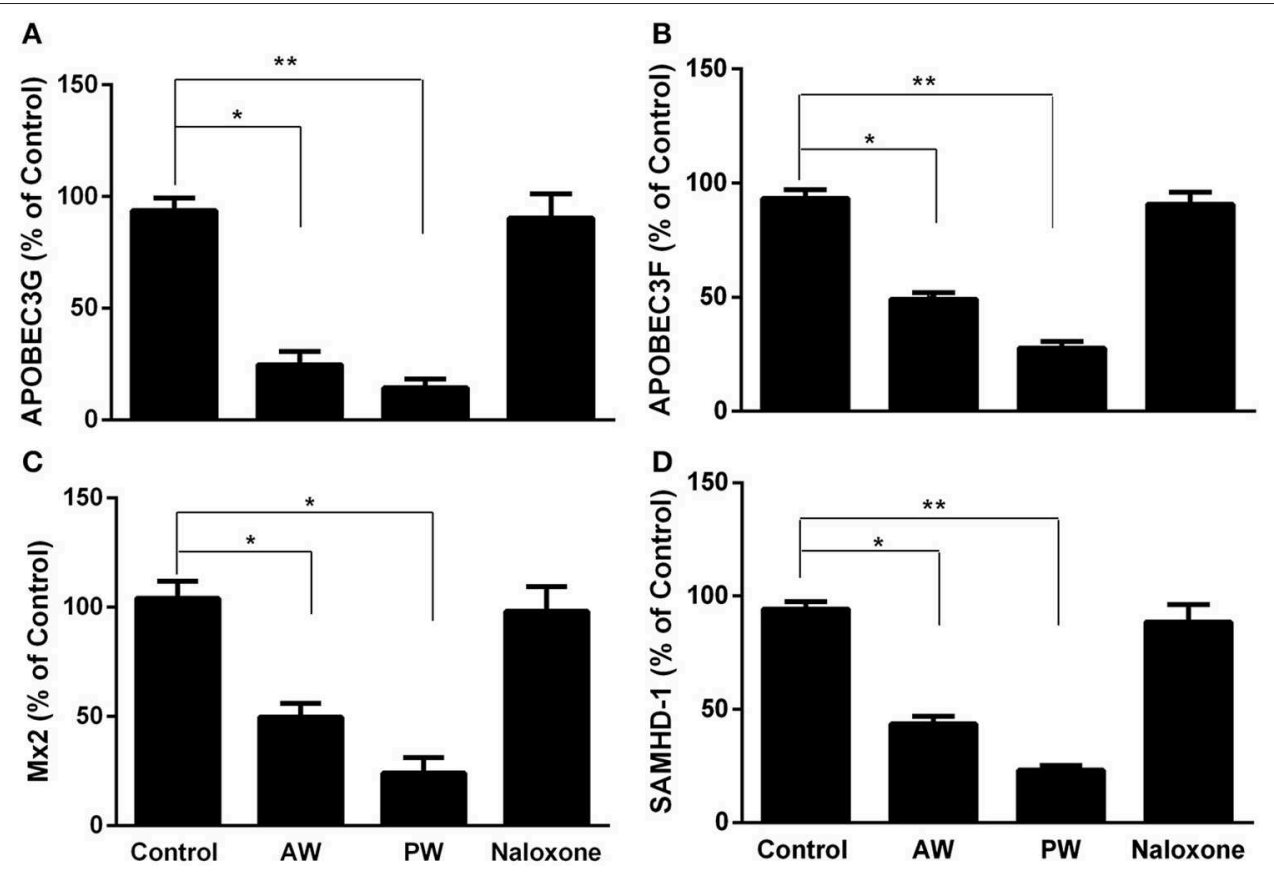

FIGURE 4 | Effect of AW or PW on cellular anti-HIV factor expression in macrophages. Seven-day-cultured macrophages were incubated with or without morphine $\left(10^{-10} \mathrm{M}\right)$ for $96 \mathrm{~h}$, followed by AW or PW for $6 \mathrm{~h}$. For PW, naloxone $\left(10^{-8} \mathrm{M}\right)$ was added to the cell cultures 3 min after morphine was removed. Total cellular RNAs were then extracted from cell cultures $6 \mathrm{~h}$ post-withdrawal and subjected to real-time RT-PCR for the mRNA expression of APOBEC3G (A), APOBEC3F (B), SAMHD-1 (C), and Mx2 (D). The data shown are the mean \pm SD of triplicate cultures, representative of three experiments using cells from three different donors $\left({ }^{*} p<0.05,{ }^{* *} p<0.01\right.$, AW or PW vs. control).

withdrawal (administration of an opioid antagonist with or without discontinuing the morphine) increases viral load in SIVinfected monkeys (25). We previously showed that morphine withdrawal manifests the enhancing effect on HIV infection of human T lymphocytes (26). Mechanistically, we observed that both morphine AW and morphine PW significantly inhibited the expression of the HIV restriction miRNAs (Figure 3A) and increased the expression of HIV replication-required miRNAs (Figure 3B). Studies have demonstrated that many miRNAs participate in the host immune responses to HIV infection (22, 27). In general, the miRNAs that interfere with HIV replication can bind to viral RNAs or indirectly disrupt viral progression by targeting the cellular factors associated with HIV replication (2830). Studies have identified multiple cellular miRNAs (miR-28, 29a, 125b, 150, 198, 223, and 382) to target a set of accessory genes of HIV (31-34). For example, HIV restriction miRNAs target the $3^{\prime} \mathrm{UTR}$ of HIV transcripts converting productive HIV replication into latency stage in resting $\mathrm{CD} 4^{+} \mathrm{T}$ cells (27). We showed that some of these miRNAs contribute to the resistance of monocytes to HIV infection (22). In addition to the inhibitory effect on the HIV restriction miRNAs, both morphine AW and PW could suppress the expression of HIV restriction cellular factors (APOBEC3G/F, SAMHD1, and MX2) (Figure 4). APOBEC3G and APOBEC3F, the key members of the APOBEC3 family, have the ability to inhibit HIV mobility (35-37). It is known that SAMHD1 can reduce the dNTPs pool in macrophages by hydrolyzing dNTPs into their precursors (nucleosides and triphosphates), resulting in inefficient HIV reverse transcription $(38,39) . \mathrm{Mx} 2$ is a HIV post-entry inhibitor that blocks the capsid-dependent nuclear import of subviral complexes (4042). Given the significant impact of these intracellular antiviral factors in the control of HIV replication, it is likely that the suppression of these elements in the HIV target cells is a sound mechanism for morphine AW- or PW-mediated enhancing effect on HIV replication in macrophages and the latently infected cells. Although these in vitro systems cannot reflect the in vivo situation where opioid withdrawal occurs repetitively during the long course of opioid abuse, they provide direct and initial evidence about the effect of morphine withdrawal on the intracellular immunity and HIV replication in macrophages, a key target and reservoir of HIV.

In summary, these data in conjunction with our earlier reports $(8,43)$ clearly demonstrate that opioid withdrawal has a negative impact on host cell innate immunity against HIV, resulting in HIV infection and persistence in the primary target cells. While future in vivo studies are necessary in order to confirm our in vitro observations, these findings have provided additional experimental evidence to support the notion that opioid abuse not only contributes to HIV transmission but also facilitates HIV replication in the target cells. 


\section{DATA AVAILABILITY STATEMENT}

The datasets generated for this study are available on request to the corresponding author.

\section{AUTHOR CONTRIBUTIONS}

$\mathrm{XW}, \mathrm{LZ}, \mathrm{JL}$, and $\mathrm{W}-\mathrm{ZH}$ conceived and designed the experiments. XW, LZ, and JL performed the experiments.

\section{REFERENCES}

1. Govitrapong P, Suttitum T, Kotchabhakdi N, Uneklabh T. Alterations of immune functions in heroin addicts and heroin withdrawal subjects. $J$ Pharmacol Exp Ther. (1998) 286:883-9.

2. Rahim RT, Adler MW, Meissler JJ Jr, Cowan A, Rogers TJ, Geller EB, et al. Abrupt or precipitated withdrawal from morphine induces immunosuppression. J Neuroimmunol. (2002) 127:88-95. doi: 10.1016/S0165-5728(02)00103-0

3. Peterson PK, Gekker G, Hu S, Anderson WR, Kravitz F, Portoghese PS, et al. Morphine amplifies HIV-1 expression in chronically infected promonocytes cocultured with human brain cells. J Neuroimmunol. (1994) 50:167-75. doi: 10.1016/0165-5728(94)90043-4

4. Stefano GB, Scharrer B, Smith EM, Hughes TK, Magazine HI, Bilfinger TV, et al. Opioid and opiate immunoregulatory processes. Crit Rev Immunol. (1996) 16:109-44. doi: 10.1615/CritRevImmunol.v16.i2.10

5. Guo CJ, Li Y, Tian S, Wang X, Douglas SD, Ho WZ. Morphine enhances HIV infection of human blood mononuclear phagocytes through modulation of beta-chemokines and CCR5 receptor. J Invest Med. (2002) 50:43542. doi: 10.1097/00042871-200211010-00027

6. Li Y, Merrill JD, Mooney K, Song L, Wang X, Guo CJ, et al. Morphine enhances HIV infection of neonatal macrophages. Pediatr Res. (2003) 54:2828. doi: 10.1203/01.PDR.0000074973.83826.4C

7. Li Y, Wang X, Tian S, Guo CJ, Douglas SD, Ho WZ. Methadone enhances human immunodeficiency virus infection of human immune cells. J Infect Dis. (2002) 185:118-22. doi: 10.1086/338011

8. Wang X, Ma TC, Li JL, Zhou Y, Geller EB, Adler MW, et al. Heroin inhibits HIV-restriction miRNAs and enhances HIV infection of macrophages. Front Microbiol. (2015) 6:1230. doi: 10.3389/fmicb.2015.01230

9. Samikkannu T, Ranjith D, Rao KV, Atluri VS, Pimentel E, El-Hage N, et al. HIV-1 gp120 and morphine induced oxidative stress: role in cell cycle regulation. Front Microbiol. (2015) 6:614. doi: 10.3389/fmicb.2015.00614

10. Wang $X$, Ho WZ. Drugs of abuse and HIV infection/replication: implications for mother-fetus transmission. Life Sci. (2011) 88:9729. doi: 10.1016/j.lfs.2010.10.029

11. Wang X, Ye L, Zhou Y, Liu MQ, Zhou DJ, Ho WZ. Inhibition of anti-HIV microRNA expression: a mechanism for opioid-mediated enhancement of HIV infection of monocytes. Am J Pathol. (2011) 178:417. doi: 10.1016/j.ajpath.2010.11.042

12. Boland JW, McWilliams K, Ahmedzai SH, Pockley AG. Effects of opioids on immunologic parameters that are relevant to anti-tumour immune potential in patients with cancer: a systematic literature review. Br J Cancer. (2014) 111:866-73. doi: 10.1038/bjc.2014.384

13. Brack A, Rittner HL, Stein C. Immunosuppressive effects of opioids-clinical relevance. J Neuroimmune Pharmacol. (2011) 6:490-502. doi: 10.1007/s11481-011-9290-7

14. Eisenstein TK. Opioids and the immune system: what is their mechanism of action? Br J Pharmacol. (2011) 164:18268. doi: 10.1111/j.1476-5381.2011.01513.x

15. Pomorska DK, Gach K, Janecka A. Immunomodulatory effects of endogenous and synthetic peptides activating opioid receptors. Mini Rev Med Chem. (2014) 14:1148-55. doi: 10.2174/13895575156661501010 95237
$\mathrm{XW}$ and LZ analyzed the data. XW created the figures. $\mathrm{W}-\mathrm{ZH}$ contributed reagents, materials, and analysis tools. $\mathrm{XW}$ and $\mathrm{W}-\mathrm{ZH}$ wrote the manuscript. All authors reviewed the manuscript.

\section{FUNDING}

This study was supported by the National Institutes of Health grants DA041302, DA042373, and DA045568.
16. Wang J, Charboneau R, Balasubramanian S, Barke RA, Loh HH, Roy S The immunosuppressive effects of chronic morphine treatment are partially dependent on corticosterone and mediated by the mu-opioid receptor. $J$ Leukoc Biol. (2002) 71:782-90.

17. Folks TM, Justement J, Kinter A, Dinarello CA, Fauci AS. Cytokine-induced expression of HIV-1 in a chronically infected promonocyte cell line. Science. (1987) 238:800-2. doi: 10.1126/science.3313729

18. Folks TM, Justement J, Kinter A, Schnittman S, Orenstein J, Poli G, et al. Characterization of a promonocyte clone chronically infected with HIV and inducible by 13-phorbol-12-myristate acetate. J Immunol. (1988) 140:111722.

19. Butera ST, Perez VL, Besansky NJ, Chan WC, Wu BY, Nabel GJ, et al. Extrachromosomal human immunodeficiency virus type-1 DNA can initiate a spreading infection of HL-60 cells. J Cell Biochem. (1991) 45:36673. doi: $10.1002 /$ jcb. 240450410

20. Butera ST, Roberts BD, Lam L, Hodge T, Folks TM. Human immunodeficiency virus type 1 RNA expression by four chronically infected cell lines indicates multiple mechanisms of latency. J Virol. (1994) 68:2726-30.

21. Willey RL, Smith DH, Lasky LA, Theodore TS, Earl PL, Moss B, et al. In vitro mutagenesis identifies a region within the envelope gene of the human immunodeficiency virus that is critical for infectivity. J Virol. (1988) 62:139-47.

22. Wang X, Ye L, Hou W, Zhou Y, Wang YJ, Metzger DS, et al. Cellular microRNA expression correlates with susceptibility of monocytes/macrophages to HIV-1 infection. Blood. (2009) 113:671-4. doi: 10.1182/blood-2008-09-175000

23. Chiang K, Liu H, Rice AP. miR-132 enhances HIV-1 replication. Virology. (2013) 438:1-4. doi: 10.1016/j.virol.2012.12.016

24. Farberov L, Herzig E, Modai S, Isakov O, Hizi A, Shomron N. MicroRNAmediated regulation of p21 and TASK1 cellular restriction factors enhances HIV-1 infection. J Cell Sci. (2015) 128:1607-16. doi: 10.1242/jcs.167817

25. Donahoe RM. Neuroimmunomodulation by opiates: relationship to HIV infection and AIDS. Adv Neuroimmunol. (1993) 3:31-46. doi: 10.1016/S0960-5428(06)80057-4

26. Wang X, Douglas SD, Peng JS, Zhou DJ, Wan Q, Ho WZ. An in vitro model of morphine withdrawal manifests the enhancing effect on human immunodeficiency virus infection of human $\mathrm{T}$ lymphocytes through the induction of substance P. Am J Pathol. (2006) 169:166370. doi: 10.2353/ajpath.2006.060358

27. Huang J, Wang F, Argyris E, Chen K, Liang Z, Tian H, et al. Cellular microRNAs contribute to HIV-1 latency in resting primary $\mathrm{CD}^{+}{ }^{+} \mathrm{T}$ lymphocytes. Nat Med. (2007) 13:1241-7. doi: 10.1038/nm1639

28. Chen AK, Sengupta P, Waki K, Van Engelenburg SB, Ochiya T, Ablan $\mathrm{SD}$, et al. MicroRNA binding to the HIV-1 Gag protein inhibits Gag assembly and virus production. Proc Natl Acad Sci USA. (2014) 111:E267683. doi: $10.1073 /$ pnas. 1408037111

29. Klase Z, Houzet L, Jeang KT. MicroRNAs and HIV-1: complex interactions. J Biol Chem. (2012) 287:40884-90. doi: 10.1074/jbc.R112.415448

30. Swaminathan S, Murray DD, Kelleher AD. The role of microRNAs in HIV-1 pathogenesis and therapy. AIDS. (2012) 26:132534. doi: 10.1097/QAD.0b013e328352adca

31. Ahluwalia JK, Khan SZ, Soni K, Rawat P, Gupta A, Hariharan M, et al. Human cellular microRNA hsa-miR-29a interferes with viral 
nef protein expression and HIV-1 replication. Retrovirology. (2008) 5:117. doi: 10.1186/1742-4690-5-117

32. Hariharan M, Scaria V, Pillai B, Brahmachari SK. Targets for human encoded microRNAs in HIV genes. Biochem Biophys Res Commun. (2005) 337:12148. doi: 10.1016/j.bbrc.2005.09.183

33. Nathans R, Chu CY, Serquina AK, Lu CC, Cao H, Rana TM. Cellular microRNA and P bodies modulate host-HIV-1 interactions. Mol Cell. (2009) 34:696-709. doi: 10.1016/j.molcel.2009.06.003

34. Sung TL, Rice AP. miR-198 inhibits HIV-1 gene expression and replication in monocytes and its mechanism of action appears to involve repression of cyclin T1. PLoS Pathog. (2009) 5:e1000263. doi: 10.1371/journal.ppat.10 00263

35. Chiu YL, Soros VB, Kreisberg JF, Stopak K, Yonemoto W, Greene WC. Cellular APOBEC3G restricts HIV-1 infection in resting CD4 ${ }^{+}$T cells. Nature. (2005) 435:108-14. doi: 10.1038/nature03493

36. Mbisa JL, Bu W, Pathak VK. APOBEC3F and APOBEC3G inhibit HIV1 DNA integration by different mechanisms. J Virol. (2010) 84:52509. doi: 10.1128/JVI.02358-09

37. Wang FX, Huang J, Zhang H, Ma X, Zhang H. APOBEC3G upregulation by alpha interferon restricts human immunodeficiency virus type 1 infection in human peripheral plasmacytoid dendritic cells. J Gen Virol. (2008) 89(Pt 3):722-30. doi: 10.1099/vir.0.83530-0

38. Berger A, Sommer AF, Zwarg J, Hamdorf M, Welzel K, Esly N, et al. SAMHD1-deficient CD14 ${ }^{+}$cells from individuals with Aicardi-Goutieres syndrome are highly susceptible to HIV-1 infection. PLoS Pathog. (2011) 7:e1002425. doi: 10.1371/journal.ppat.1002425
39. Hrecka K, Hao C, Gierszewska M, Swanson SK, Kesik-Brodacka M, Srivastava $\mathrm{S}$, et al. Vpx relieves inhibition of HIV-1 infection of macrophages mediated by the SAMHD1 protein. Nature. (2011) 474:658-61. doi: 10.1038/nature10195

40. Goujon C, Moncorge O, Bauby H, Doyle T, Ward CC, Schaller T, et al. Human MX2 is an interferon-induced post-entry inhibitor of HIV-1 infection. Nature. (2013) 502:559-62. doi: 10.1038/nature12542

41. Kane M, Yadav SS, Bitzegeio J, Kutluay SB, Zang T, Wilson SJ, et al. MX2 is an interferon-induced inhibitor of HIV-1 infection. Nature. (2013) 502:5636. doi: 10.1038/nature12653

42. Liu Z, Pan Q, Ding S, Qian J, Xu F, Zhou J, et al. The interferon-inducible MxB protein inhibits HIV-1 infection. Cell Host Microbe. (2013) 14:398410. doi: 10.1016/j.chom.2013.08.015

43. Wang Y, Wang X, Ye L, Li J, Song L, Fulambarkar N, et al. Morphine suppresses IFN signaling pathway and enhances AIDS virus infection. PLoS ONE. (2012) 7:e31167. doi: 10.1371/journal.pone.0031167

Conflict of Interest: The authors declare that the research was conducted in the absence of any commercial or financial relationships that could be construed as a potential conflict of interest.

Copyright (c) 2019 Wang, Liu, Zhou and Ho. This is an open-access article distributed under the terms of the Creative Commons Attribution License (CC BY). The use, distribution or reproduction in other forums is permitted, provided the original author(s) and the copyright owner(s) are credited and that the original publication in this journal is cited, in accordance with accepted academic practice. No use, distribution or reproduction is permitted which does not comply with these terms. 